This PDF file of your paper in Environmental Archaeology vol. 10,2 belongs to the publishers Oxbow Books and is their copyright.

As author you are licenced to make up to 50 offprints from it, but beyond that we ask you not to publish it on the World Wide Web or in any other form without prior permission. 


\title{
Modern Coleoptera from Non-cereal Thatch: A Poor Analogue for Roofing Material from the Archaeological Record
}

\author{
David N. Smith, John Letts and Mike Jones
}

\begin{abstract}
Five Coleoptera faunas recovered from modern non-cereal roofing thatches (potato stem, bracken, water reed, heather and gorse) were analysed to determine whether phytophage taxa contained in the thatch would correspond to the material used. The absence of matching phytophage species suggests that these insects would have limited potential to allow the identification of these types of roofing material in the archaeological record.
\end{abstract}

Keywords: Coleoptera, Roofing Thatch Materials, Modern Parallels, Palaeoentomological Interpretation

\section{Introduction and Previous Work}

Two previous papers (Smith 1996a; Smith et al. 1999) have discussed the potential of modern insect remains from a variety of roofing thatches to function as analogues for their remains in the archaeological record.

Smith (1996a) described and discussed the beetle faunas from a series of thatch samples from black-houses in the Outer Hebrides. All of the samples came from thick thatch deposits made up of a local 'bent grass' and came from the middle layers of the roof just below the exposed surface material. It was found that this material often contained a relatively distinctive beetle fauna dominated by the small endomychid Mycetaea hirta, two species of spider beetle, Tipnus unicolor and Ptinus fur, Corylophus and Ptiliidae species (see Table 1, which presents the five dominant taxa for these and other thatch samples discussed here). Though these faunas appeared to be distinctive it was suggested that it would be dangerous to use them alone to indicate the presence of thatch in the archaeological record. The difficulty lay with the fact that it was impossible to limit the occurrence of these species only to thatch. This group of beetles appears to indicate the microhabitats in thatch rather than thatch per se. A range of other materials in the archaeological record might contain similar microhabitats and produce a similar insect fauna thus confusing interpretation. One suggested solution to this problem was to use other forms of environmental and archaeological evidence such as plant remains, position in site stratigraphy and the presence of roof 'furniture' (such as rafters, battens and wood-en bonds, spars and sways used to fix thatch onto the roof structure) along with the insect fauna to indicate roofing thatch. In essence, it was con-cluded that the use of an 'indicator package' for thatch similar to that outlined for stable manure by Kenward and Hall (1997)would be the best approach. An example of such an exercise in the interpretation of both biological and archaeological records to suggest the presence of thatch is the discussion by Moffet and Smith (1996) of deposits at Stone, Staffordshire, UK.

In a subsequent paper, Smith et al. (1999) presented the results of a survey of Coleoptera contained in pre-16th century AD smoke-blackened cereal thatch. This material was derived from deep within the internal layers of thatching material and was often from directly above the roof

Received July 2004, revised manuscript accepted January 2005.

Authors' addresses: David Smith and Mike Jones, Institute of Archaeology and Antiquity, University of Birmingham, Edgbaston, Birmingham, B15 2TT, UK, Email: d.n.smith@bham.ac.uk; John Letts, Historic Thatch Management Ltd., 26 Addison Cresent, Oxford, OX4 4DB, UK. 


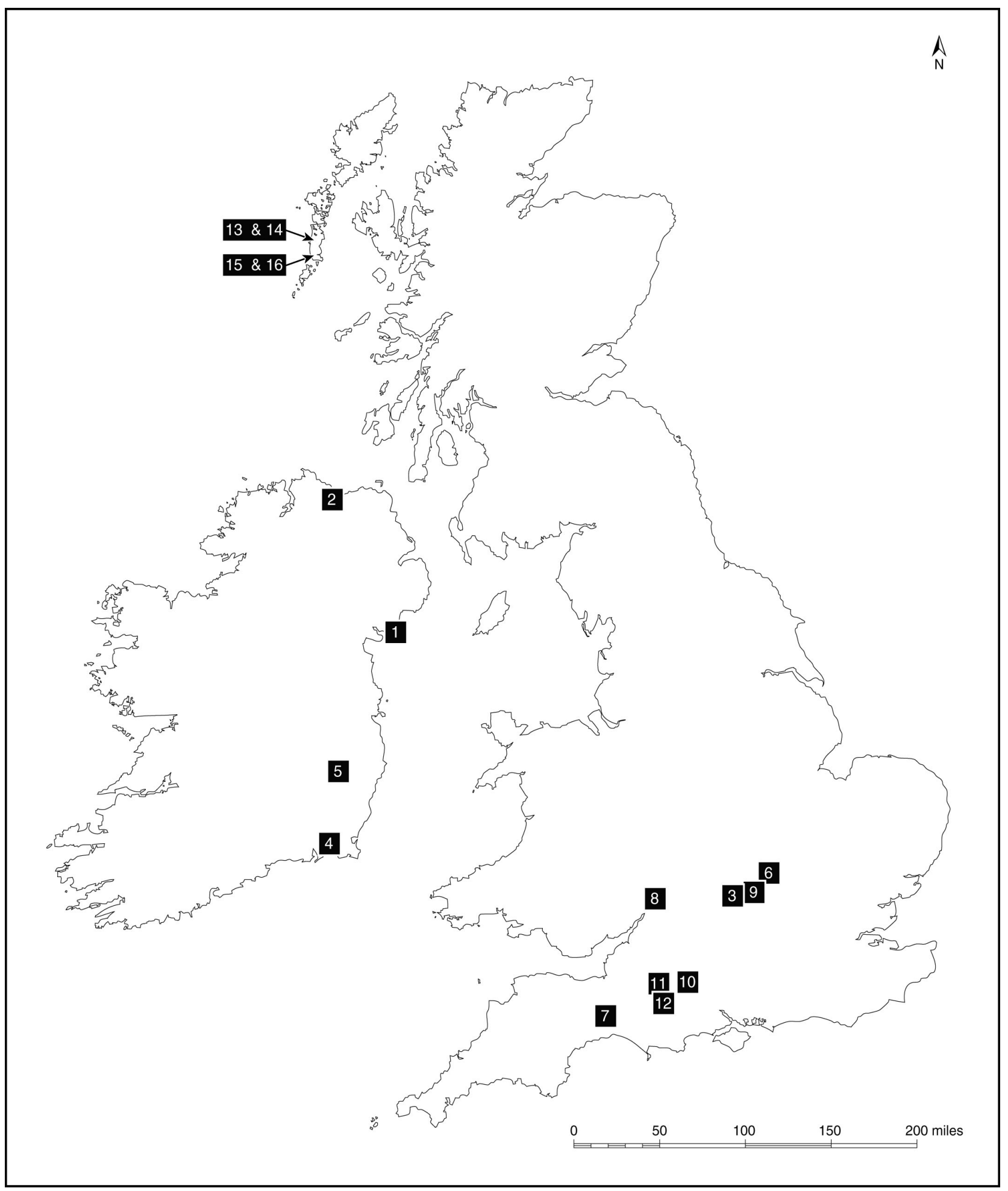

Figure 1. Location of sites mentioned in text. 1. Annalong, County Down; 2. Magilligans Point, County Londonderry; 3. Stanton St. John, Oxfordshire; 4. Licketstown, County Kilkenny; 5. Knockananna, County Wicklow; 6. Willow Vale Farm, Steeple Claydon, Buckinghamshire; 7 Tytherleigh Cottage, Chardstock, Devon; 8. Primrose Cottage, Upton St. Leonards, Portway, Gloucestershire; 9. Priests End, Thame, Oxfordshire; 10 Little Orchard, Bardord St. Martin, Salisbury, Wiltshire; 11. Elm Tree Cottage, Panters Road, Sutton Mandeville, Wiltshire; 12. Robin Cottage, High Street, Tisbury, Wiltshire; 13. South Loch Boisdale, Uist, Outer Hebrides; 14. Howbeg, Uist, Outer Hebrides; 15. Howmore, Uist, Outer Hebrides; 16. Askernish, Uist, Outer Hebrides. 


\begin{tabular}{|c|c|c|c|c|c|c|}
\hline & & Rank 1 & Rank 2 & Rank 3 & Rank 4 & Rank 5 \\
\hline \multirow{5}{*}{ 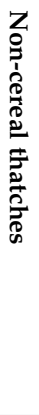 } & Anna 1 & $\begin{array}{l}\text { Pentarthrum huttoni } \\
\text { (Woll.) }\end{array}$ & $\begin{array}{l}\text { Mycetaea hirta } \\
\text { (Marsh.) }\end{array}$ & $\begin{array}{l}\text { Anobium punctatum } \\
\text { (Geer.) }\end{array}$ & Ptiliidae spp. & $\begin{array}{l}\text { Tipnus unicolor } \\
\text { (Pill. \& Mitt.) } \\
\text { Ptinus fur (L.) }\end{array}$ \\
\hline & McG.Pt-1 & Ptinus fur & Mycetaea hirta & $\begin{array}{l}\text { Single individuals of } \\
\text { many taxa }\end{array}$ & - & - \\
\hline & St.StJ -1 & Anobium punctatum & Mycetaea hirta & Corticaria spp & $\begin{array}{l}\text { Ptinus fur } \\
\text { Megasturum } \\
\text { obscurum (Marsh.) }\end{array}$ & - \\
\hline & Kilk-1 & $\begin{array}{l}\text { Mycetaea hirta } \\
\text { Cryptophagus sp. }\end{array}$ & - & $\begin{array}{l}\text { Apion spp. } \\
\text { Corticaria spp. } \\
\text { Ptinus fur }\end{array}$ & - & - \\
\hline & Wick-1 & Anobium punctatum & Mycetaea hirta & $\begin{array}{l}\text { Euophyrum confine } \\
\text { (Broun) }\end{array}$ & Corticaria spp. & Sitona spp. \\
\hline \multirow{10}{*}{ 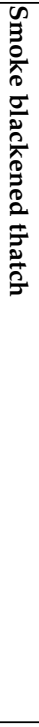 } & Wilt [I] 1 & Anobium punctatum & Ptinus fur & Corticaria spp. & $\begin{array}{l}\text { Xestobium } \\
\text { rufovillosum (Deg.) }\end{array}$ & $\begin{array}{l}\text { Single individuals of } \\
\text { many taxa }\end{array}$ \\
\hline & Wlit [I] 2 & $\begin{array}{l}\text { Anobium punctatum } \\
\text { Ptinus fur }\end{array}$ & - & Tipnus unicolor & $\begin{array}{l}\text { Corticaria spp. } \\
\text { Xestobium } \\
\text { rufovillosum }\end{array}$ & - \\
\hline & Gloucs [22] & Anobium punctatum & $\begin{array}{l}\text { Cryptophagus spp } \\
\text { Phyllotreta sp. }\end{array}$ & - & $\begin{array}{l}\text { Single individuals } \\
\text { of many taxa }\end{array}$ & - \\
\hline & Oxon [25] & Anobium punctatum & $\begin{array}{l}\text { Cryptophagus pilosus } \\
\text { Corticaria spp. } \\
\text { Anthrenus museorum (L.) }\end{array}$ & - & - & - \\
\hline & Wilts $[\mathrm{H}] 1$ & Anobium punctatum & Xestobium rufovillosum & $\begin{array}{l}\text { Cryptopleurum minutum } \\
\text { (Fab.) } \\
\text { Quedius spp. } \\
\text { Sitona spp. }\end{array}$ & - & - \\
\hline & Wilts $[\mathrm{H}] 2$ & Anobium punctatum & $\begin{array}{l}\text { Corticaria spp. } \\
\text { Cryptophagus sp. }\end{array}$ & - & Ptinus fur & Mycetaea hirta \\
\hline & Bucks [2] 1 & Anobium punctatum & Tipnus unicolor & Ptinus fur & Corticaria spp. & Bruchus pisorum (L.) \\
\hline & Bucks [2] 2 & Ptinus fur & Anobium punctatum & Tipnus unicolor & Corticaria spp. & Attagenus pellio (L.) \\
\hline & Wilts [33] & Anobium punctatum & Ptinus fur & Necrobia rufipes (Deg.) & $\begin{array}{l}\text { Xestobium } \\
\text { rufovillosum }\end{array}$ & $\begin{array}{l}\text { Cryptophagus scanicus } \\
\text { (L.) }\end{array}$ \\
\hline & Devon [17] & Anobium punctatum & $\begin{array}{l}\text { Xestobium rufovillosum } \\
\text { Tipnus unicolor } \\
\text { Corticaria spp. }\end{array}$ & - & - & Ptinus fur \\
\hline \multirow{9}{*}{ 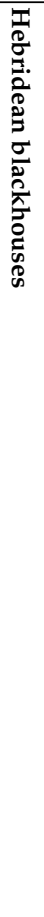 } & SLB 2 & Mycetaea hirta & Ptillidae & Atomaria spp. & $\begin{array}{l}\text { Acrotrichis sp. } \\
\text { Quedius spp. } \\
\text { Corticaria spp. }\end{array}$ & - \\
\hline & HB 1 & Mycetaea hirta & $\begin{array}{l}\text { Corylophus spp. } \\
\text { Acrotrichus spp. } \\
\text { Corticaria spp. }\end{array}$ & - & - & - \\
\hline & HB 2 & Mycetaea hirta & $\begin{array}{l}\text { Corylophus spp. } \\
\text { Lathridius minutus (L.) }\end{array}$ & - & $\begin{array}{l}\text { Micropeplus } \\
\text { porcatus (Payk.) } \\
\text { Othius spp. } \\
\text { Quedius spp } \\
\text { Atomaria spp. }\end{array}$ & - \\
\hline & HB 3 & Mycetaea hirta & Tipnus unicolor & Corylophus spp. & Atomaria spp. & $\begin{array}{l}\text { Philonthus spp. } \\
\text { Quedius spp. } \\
\text { Lathridius minutus } \\
\text { Aphodius ater (Deg.) }\end{array}$ \\
\hline & HM 1 & Mycetaea hirta & Corticaria spp. & $\begin{array}{l}\text { Ptiliidae gen. et spp. } \\
\text { indet }\end{array}$ & Cryptophagus spp. & Apion spp. \\
\hline & HM 2 & Mycetaea hirta & Corylophus spp. & Cryptophagus spp. & $\begin{array}{l}\text { Corticaria spp. } \\
\text { Tipnus unicolor }\end{array}$ & - \\
\hline & HM 3 & Tipnus unicolor & Mycetaea hirta & Corticaria spp. & Corylophus spp. & $\begin{array}{l}\text { Ptiliidae gen. et spp. } \\
\text { indet }\end{array}$ \\
\hline & AS 1 & Mycetaea hirta & Corylophus spp. & Cryptophagus spp. & $\begin{array}{l}\text { Only one } \\
\text { individual exists of } \\
\text { many species }\end{array}$ & - \\
\hline & AS 2 & Mycetaea hirta & Enicmus minutus & $\begin{array}{l}\text { Corylophus spp. } \\
\text { Acrotrichis spp. }\end{array}$ & $\begin{array}{l}\text { Cryptophagus sp. } \\
\text { Donacia spp. }\end{array}$ & - \\
\hline
\end{tabular}

Table 1. The five most abundant taxa recovered from three roofing thatch materials. Anna-1=Annalong, County Down, Northern Island; McG.P.-1=McGilligans Point, Co. Londonderry, Northern Island; St.StJ.=Stanton St. John, Oxfordshire, England; Kilk-1=Licketstown, Co. Kilkenny, Ireland; Wick-1=Knockananna, Co. Wicklow, Ireland; Bucks [2]=Willow Vale Farm, Steeple Claydon, Buckinghamshire, England; Devon [17]=Tytherleigh Cottage, Chardstock, Devon, England; Gloucs [22]=Primrose Cottage, Upton St. Leonards, Portway, Gloucestershire, England; Oxon [25]=Priests End, Thame, Oxfordshire, England; Wilts [I]=Little Orchard, Barford St. Martin, Salisbury, Wiltshire, England; Wilts $[H]=E l m$ Tree Cottage, Panters Rd, Sutton Mandeville, Wiltshire, England; Wilts [33] =Robin Cottage, High Street, Tisbury, Wiltshire, England; SLB=South Loch Boisdale, Uist, Outer Hebrides, Scotland; HB=Howbeg, Uist, Outer Hebrides, Scotland; HM=Howmore, Uist, Outer Hebrides, Scotland; AS=Askernish, Uist, Outer Hebrides, Scotland. 
rafters. Once again a similar set of insects was found across many samples (see the five dominant taxa for these sites in Table 1). In this case the faunas appeared to be dominated by anobiids such as the common woodworm beetle Anobium punctatum and the death watch beetle Xestobium rufovillosum, and a range of spider beetles and Cryptophagus and Corticaria species associated with dry organic materials. Other species that were persistently encountered were Anthrenus museorum, Attagenus pellio and Necrobia rufipes. These too are all associated with dry organic materials such as bone, skin and hair, and they are often associated with bird nests (Hickin 1964; Woodroffe and Southgate 1952). It was suggested that these faunas differed from those recovered in the Hebrides because they came from the almost desiccated dry interior of the roofs rather than the more humid middle layer of thatching just below the weathered surface deposits. It was also suggested that the faunas from the Hebrides and from the smoke-blackened thatch might represent different elements of a succession within decaying thatch (Smith et al. 1999). A similar succession has been recorded in microbial and fungal decay patterns in thatch roofs (Kirby and Raynor 1988; 1989). Since both sets of material were internal to the thatch, it was suggested that any geographic and climatic differences between the two areas would be reduced. Though the fauna from the innermost layers of the roof appears to be relatively discrete and distinctive, it was impossible to suggest that insect remains alone could be used to identify the presence of roofing material in the archaeological record.

In the conclusions to the 1999 paper (Smith et al. 1999) it was suggested that there might be a potential solution to this problem. It was hypothesised that in non-cereal thatches and roofing materials, such as heather (Calluna vulgaris (L.) Hull), gorse (Ulex europaeus L.) and water reed (Phragmites australis (Cav.) Trin. ex Steud.), phytophage insect species associated with these plants might be encountered in sufficient numbers to directly indicate what material had been used in thatching. This paper outlines the results of examination of modern examples of such non-cereal roofing thatch in order to assess if this is the case. The insects encountered in heather, gorse, water reed, bracken (Pteridium aquilinum (L.) Kuhn) and potato (Solanum tuberosum L.) stem thatches are described.

\section{Sampling Location, Type and Laboratory Methodology}

The samples were recovered by John Letts from a variety of locations in the British Isles and Ireland in 1996 and 1997. The geographical location of the sampling sites is shown in Fig. 1, and the detailed location, nature of the thatch sampled and a description of the use of the building are given in Table 2.

\begin{tabular}{|c|c|c|c|c|}
\hline & $\begin{array}{l}\text { Site name and } \\
\text { location }\end{array}$ & $\begin{array}{l}\text { Date of } \\
\text { Building }\end{array}$ & Description & Thatch \\
\hline Anna 1 & $\begin{array}{l}\text { Annalong, Co. } \\
\text { Down, } \\
\text { Northern } \\
\text { Ireland }\end{array}$ & $\begin{array}{l}\text { Mid } 18^{\text {th }} \\
\text { century }\end{array}$ & $\begin{array}{l}\text { Derelict partly } \\
\text { collapsed } \\
\text { house }\end{array}$ & $\begin{array}{l}\text { Potato (Solanum tuberosum L.) stem } \\
\text { overlying turf attached with straw ties } \\
\text { and blackberry (Rubus fruticosus L.agg.) } \\
\text { stem scallops followed by top coat of } \\
\text { common water reed (Phagmites australis } \\
\text { (Cav.) Trin. ex Steud) }\end{array}$ \\
\hline McG.Pt-1 & $\begin{array}{l}\text { McGilligans } \\
\text { Point, Co. } \\
\text { Londonderry, } \\
\text { Northern } \\
\text { Ireland }\end{array}$ & $19^{\text {th }}$ century & $\begin{array}{l}\text { Derelict partly } \\
\text { collapsed } \\
\text { house }\end{array}$ & $\begin{array}{l}\text { Bracken (Pteridium aquilinum (L.) Kuhn) } \\
\text { overlying turf and followed by a top coat } \\
\text { of eel and bent grasses (Zostera spp., } \\
\text { Ammophila sp.) }\end{array}$ \\
\hline St.StJ -1 & $\begin{array}{l}\text { Stanton St. } \\
\text { John, } \\
\text { Oxfordshire, } \\
\text { England. }\end{array}$ & c. 1801 & 6 bay cartshed & $\begin{array}{l}\text { Gorse (Ulex europaeus L.) bound into } \\
\text { faggots (with some bracken Pteridium } \\
\text { aquilinum covered with blackthorn } \\
\text { (Prunus spinosa L.) brushwood and a } \\
\text { topcoat of cereal straw and Phragmites } \\
\text { australis }\end{array}$ \\
\hline Kilk-1 & $\begin{array}{l}\text { Licketstown, } \\
\text { County } \\
\text { Kikenny, } \\
\text { Ireland }\end{array}$ & $19^{\text {th }}$ century & $\begin{array}{l}\text { Derelict partly } \\
\text { collapsed } \\
\text { house }\end{array}$ & $\begin{array}{l}\text { Both base and main coat composed of } \\
\text { Phragmites australis }\end{array}$ \\
\hline Wick-1 & $\begin{array}{l}\text { Knockananna, } \\
\text { Co. Wicklow, } \\
\text { Ireland }\end{array}$ & $19^{\text {th }}$ century & $\begin{array}{l}\text { Derelict partly } \\
\text { collapsed } \\
\text { house }\end{array}$ & $\begin{array}{l}\text { Basecoat of heather (Calluna vulgaris (L.) } \\
\text { Hull) overlying turf and covered with } \\
\text { topcoat of sedge (Carex spp.) }\end{array}$ \\
\hline
\end{tabular}

Table 2. The thatch: location of buildings, their nature, and the materials sampled. 


\begin{tabular}{|c|c|c|c|c|c|}
\hline & Anna 1 & McG.Pt-1 & StaStJ -1 & Kilk-1 & Wick-1 \\
\hline \multicolumn{6}{|l|}{ CARABIDAE } \\
\hline $\begin{array}{l}\text { Trechus quadristriatus (Schrk) or obtusus } \\
\text { (Erich.) }\end{array}$ & - & - & - & - & 1 \\
\hline Bembidion sp. & - & - & - & - & 1 \\
\hline Pterostichus nigrita (Payk.) & 1 & - & - & - & - \\
\hline Agonum sp. & & - & - & - & 1 \\
\hline Amara sp. & 1 & - & 1 & - & - \\
\hline Harpalus sp. & 1 & - & - & - & - \\
\hline Bradycellus ruficollis (Steph.) & - & 1 & - & - & - \\
\hline \multicolumn{6}{|l|}{ HYDROPHIDAE } \\
\hline Helophorus sp. & - & - & 1 & - & - \\
\hline Megasternum obscurum (Marsh.) & - & - & 5 & - & - \\
\hline \multicolumn{6}{|l|}{ PTILIIDAE } \\
\hline Ptillidae gen. et spp. indet & 3 & 1 & 4 & - & - \\
\hline Acrotrichis sp. & - & - & - & - & 1 \\
\hline \multicolumn{6}{|l|}{ LEIODIDAE } \\
\hline Agathidium sp. & - & 1 & - & - & - \\
\hline \multicolumn{6}{|l|}{ STAPHYLINIDAE } \\
\hline Micropeplus staphylinodes (Marsh) & - & - & - & 1 & - \\
\hline Olophrum sp. & - & - & 1 & - & - \\
\hline Anotylus rugosus (Fab.) & - & - & 1 & - & - \\
\hline Gyrohypnus punctulatus (Payk.) & - & - & - & - & 1 \\
\hline Xantholinus spp. & - & - & 2 & - & - \\
\hline Philonthus sp. & - & - & - & - & 1 \\
\hline Quedius sp. & - & 1 & - & - & - \\
\hline Tachyporus chrysomelinus (L.) & - & - & 1 & - & - \\
\hline Aleocharinae gen. et spp. indet. & 1 & - & - & - & - \\
\hline \multicolumn{6}{|l|}{ SCARABIDAE } \\
\hline Colobopterus fossor (L.) & - & - & - & - & 1 \\
\hline Aphodius foetidus (Herbst.) & - & 1 & - & - & - \\
\hline A. sphacelatus (Panz.) & - & 1 & - & - & - \\
\hline A. spp. & 1 & - & 1 & 1 & - \\
\hline \multicolumn{6}{|l|}{ CLAMBIDAE } \\
\hline Clambus spp. & - & - & 1 & 1 & 1 \\
\hline \multicolumn{6}{|l|}{ DERMESTIDAE } \\
\hline Attagenus pellio (L.) & - & - & 1 & - & - \\
\hline \multicolumn{6}{|l|}{ ANOBIIDAE } \\
\hline Xestobium rufovillosum (Deg.) & - & - & - & - & 1 \\
\hline Anobium punctatum (Deg.) & 8 & - & 181 & 1 & 144 \\
\hline \multicolumn{6}{|l|}{ PTINIDAE } \\
\hline Tipnus unicolor (Pill. \& Mitt.) & 2 & - & - & - & - \\
\hline Ptinus fur (L.) & 2 & 4 & 5 & 2 & 1 \\
\hline \multicolumn{6}{|l|}{ CLERIDAE } \\
\hline Necrobia violacea (L.) & - & - & 2 & - & - \\
\hline \multicolumn{6}{|l|}{ CRYPTOPHAGIDAE } \\
\hline Cryptophagus acutangulus (Gyll.) & - & - & 2 & - & - \\
\hline C. spp. & 1 & - & 4 & 6 & 1 \\
\hline Atomaria sp. & - & - & 1 & 1 & 1 \\
\hline \multicolumn{6}{|l|}{ COCCINELLIDAE } \\
\hline Coccidula rufa (Herbst) & - & - & 1 & - & - \\
\hline \multicolumn{6}{|l|}{ LATHRIDIIDAE } \\
\hline Lathridius minutus (L.) & 1 & - & 2 & - & 1 \\
\hline L. sp & - & - & - & 1 & - \\
\hline Dienerella filiformis (Gyll.) & & 1 & - & - & - \\
\hline D. separanda (Reitter) & - & - & 2 & - & - \\
\hline Corticaria inconspicua (Woll.) & - & 1 & - & - & - \\
\hline C. punctulata (Marsh.) & - & - & - & - & 1 \\
\hline C. spp. & 1 & & 6 & 2 & 3 \\
\hline \multicolumn{6}{|l|}{ ANTHICIDAE } \\
\hline Anthicus sp. & - & - & 1 & - & - \\
\hline CHRYSOMELIDAE & & & & & \\
\hline Longitarsus sp. & - & - & 2 & - & - \\
\hline
\end{tabular}

Table 3. The Coleoptera recovered from non-cereal thatch. Anna-1 = Annalong, County Down, Northern Ireland; McG.P.-1 = McGilligans Point, Co. Londonderry, Northern Ireland; St.StJ. = Stanton St. John, Oxfordshire, England; Kilk-1 = Licketstown, Co. Kilkenny, Ireland; Wick-1 = Knockananna, Co. Wicklow, Ireland. 
MJ undertook the practical laboratory work and identification of the insect faunas as part of an undergraduate dissertation in 1999. Samples of thatch were sieved using a $5 \mathrm{~mm}$ mesh. After oven drying for 24 hours the samples were passed over a $3 \mathrm{~mm}$ and $300 \mu \mathrm{m}$ mesh sieve in order to remove large material. The individual fractions were then sorted under an illuminated magnifying glass at $\times 1.75$ and the beetle remains removed.

The beetles present were identified by comparison to the Gorham and Girling insect collections housed at the Institute of Archaeology and Antiquity, University of Birmingham. To compare the insect faunas recovered from the non-cereal thatches, the Hebridean thatch and the smokeblackened thatch the five most abundant taxa occurring at each site were used.

\section{Results}

The insect faunas recovered from the different noncereal thatches from a number of derelict buildings in Northern Ireland and England are presented in Table 3. The nomenclature used is based on Kloet and Hincks (1977). The five most abundant species from the various types of thatch examined are presented in rank order in Table 1.

\section{Discussion}

In general the insect faunas recovered from noncereal thatch are very similar to those from the Hebridean thatch roofs, and to a lesser extent, those recovered from smoke-blackened thatch (Smith 1996b; Smith et al. 1999). This is not surprising since the derelict nature of many of the roofs sampled for non-cereal thatch is directly

\begin{tabular}{|c|c|}
\hline Plant species & Associated Coleoptera \\
\hline Potato (Solanum tuberosum L.) & $\begin{array}{l}\text { Few species, the principal example being Psylliodes affinis } \\
\text { (Payk.) which, however, can also attack a range of other } \\
\text { plants. }\end{array}$ \\
\hline Bracken (Pteridium aqulinum (L.) Kuhn) & $\begin{array}{l}\text { Syagrius intrudens (Water.). However, this species is a recent } \\
\text { introduction to Britain (Hyman and Parsons 1992) and so } \\
\text { not relevant to the archaeological record. }\end{array}$ \\
\hline Gorse (Ulex europaeus L.) & $\begin{array}{l}\text { Micrambe vini (Panz.) } \\
\text { Calomicrus circumfusus (Marsh.) } \\
\text { Apion striatum (Marsh.) } \\
\text { Apion scutellare (Kirby) } \\
\text { Apion ulicis (Forst.) } \\
\text { Polydrusus confluens (Stephen) } \\
\text { Sitona regensteinensis (Herbst.) } \\
\text { Sitona striatellus (Gyll.) } \\
\text { Hypera venusta (Fab.) } \\
\text { Hylastinus obscurus (Marsh.) } \\
\text { Phloeophthorus rhododactylus (Marsh.) (but mainly on Broom } \\
\text { Cytisus scoparius (L.) Link agg.) }\end{array}$ \\
\hline $\begin{array}{l}\text { Common water reed (Phragmites australis } \\
\text { (Cav.) Trin. ex Steud.) }\end{array}$ & $\begin{array}{l}\text { Odocantha melanura }(\text { L.) } \\
\text { Donacia cinerea (Herbst) } \\
\text { Donacia clavipes (Fab.) } \\
\text { Plateumaris braccata (Scopoli) } \\
\text { Notaris bimaculatus (F.) (but not exclusively) }\end{array}$ \\
\hline Heather (Calluna vulgaris (L.) Hull) & $\begin{array}{l}\text { Amara infirma (Dufts.) } \\
\text { Trichocellus cognatus (Gyll.) } \\
\text { Bradycellus ruficollis (Steph.) } \\
\text { Bradycellus collaris (Payk.) } \\
\text { Ampedus sanguinolentus (Sckrk.) } \\
\text { Coccinella hieroglyphica (L.) } \\
\text { Lochmaea suturalis (Thom.) } \\
\text { Altica britteni (Sharp) } \\
\text { Altica oleracea (L.) } \\
\text { Coniocleonus nebulosus (L.) } \\
\text { Strophosomus capitatus (Deg.) } \\
\text { Strophosomus nebulosus (L.) } \\
\text { Micrelus ericae (Gyll.) }\end{array}$ \\
\hline
\end{tabular}

Table 4. Phytophage and other Coleoptera associated with the plants used in thatching (information mainly from Bullock 1992). 
comparable with the condition of many of the blackhouses examined on South Uist. This clearly supports the view that materials such as this may contain insect communities that are essentially post use rather than developed during occupation (Kenward 1978; 1985; Smith 1996a; 1998). Equally, the faunas from both sets of abandoned buildings clearly indicate that some elements of these faunas, often species that have been described as synanthropic or facultative synanthropes (e.g. Kenward 1997) are able to persist for some time after human occupation has ceased (Smith 1998). This observation has implications for recent sug-gestions that occurrence and diversity of synan-thropic insect faunas may be used to indicate the extent of continued occupation of archaeological sites (Kenward 1997).

At the start of the investigation one of the authors (MJ) drew up a list of phytophage beetles that are associated with the types of plants used in the thatch examined. It was hoped that this list would act as a 'predictor' for the range of species that might be encountered and could be indicative of the presence of these types of material in the archaeological record. This list of 'potential taxa' is presented in Table 4. However, an examination of Tables 2 and 3 indicates that very few of these phytophage taxa were actually encountered in any of the non-cereal thatch samples. There is only one case when the host plant and corresponding phytophage beetles were recovered together from thatching material - two individuals of Apion ulicis from gorse roofing at Stanton St. John. However, this in itself is of limited significance. Firstly, these two individuals account for a very small proportion of the overall fauna recovered and, therefore, give a very poor signal for the existence of gorse thatch. Equally, there are many other ways in which these two individuals of a fairly common species of beetle could have become incorporated in to the thatch in addition to coming in with the original thatching material. Kenward $(1975 ; 1978)$ has widely discussed how such typically 'outdoor' species can form part of a considerable allochthonous component in exposed material. In terms of roofing material, Kenward's (1985) description of the nature and formation of insect faunas in modern roof spaces may be particularly relevant here.

There are several ways in which the absence of phytophage taxa from the non-cereal thatch samples can be explained. It is possible that the phytophage beetles may have fallen off the vegetation when it was initially cut for thatch. Letting go of the host vegetation when it is disturbed is a common defence mechanism, particularly amongst the weevils. Equally, phytophage species have been observed leaving freshly cut fodder as it began to dry in storage (Smith 1998) and a similar circumstance may occur in freshly cut roofing material. Added to this must be the factor of biological decay over the relatively long period of time between thatching and sampling in this study. At present the time it takes for the sclerites of insects to decay in dry sheltered environments, such as the interior of roofing thatch, is not clear. However, several of the sclerites found in these samples showed evident signs of decay or having been partially consumed by other insects. If phytophage insects were in-corporated into the non-cereal thatch when it was initially laid their remains may have been destroyed a long time ago, so that the fauna recovered from these samples represents more recent colonists.

\section{Conclusion}

Despite the initial promise of this material, and a degree of optimism at the start of this study, it is clear that phytophage insects by themselves do not provide a strong interpretive tool to add in the identification of roofing thatch in the archaeological record. Once again the insects can only be used to broadly confirm the existence of thatch where this interpretation is suggested by a range of other indicators. This study has confirmed again that there is a distinct set of insect species associated with roofing thatch, even if elements of this fauna are not restricted to thatch alone, so that it has poor potential in terms of direct archaeological interpretation of the exact materials used.

It is clear that thatch and other forms of roofing have clear potential to contribute large amounts of material to the archaeological record. The detection of these deposits is an important part of understanding site formation. Despite three papers (Smith 1996a and b; Smith et al. 1999) showing that insects appear to have only a confirming role in the identification of roofing material there is still more work to be done. A wide range of materials, including hay, might be used in roofing, especially for temporary buildings. Both Kenward and Hall (1997) and Smith (1998) have clearly indicated that a 'hay fauna' of insects exists archaeologically. Further research should perhaps be aimed at establishing the composition of the insect fauna associated with hay used as thatching. Although two studies of roofing turfs exist (Kenward et al. 1984; Smith 1996a), insect faunas associated with them are still under-investigated. 


\section{Acknowledgements}

The authors would like to thank the various owners of the buildings sampled for permission to remove material and Wendy Smith and Harry Kenward who made various helpful suggestions on earlier drafts of this paper.

\section{References}

Bullock, J. A. 1992. Host plants of British beetles: A list of recorded associations. The Amateur Entomologist 11, 1-24.

Hickin, N. E. 1964. Household Insect Pests. London: Hutchinson.

Kenward, H. K. 1975. Pitfalls in the environmental interpretation of insect death assemblages. Journal of Archaeological Science 2, 85-94.

Kenward, H. K. 1978. The Analysis of Archaeological Insect Assemblages: a New Approach. (The Archaeology of York 19/ 1). London: Council for British Archaeology.

Kenward, H. K. 1985. OutdoorIndoors? The outdoor component of archaeological insect assemblages, pp. 97-104 in Fieller, N. R. J., Gilbertson, D. D. and Ralph, N. G. A. (eds.), Palaeobiological Investigations: Research Design, Methods and Data Analysis (BAR S266). Oxford: British Archaeological Reports.

Kenward, H. K. 1997. Synanthropic insects and the size, remoteness and longevity of archaeological occupation sites: applying concepts from biogeography to past "islands" of human occupation. Quaternary Proceedings 5, 135-52.

Kenward, H. K. and Hall, A. R. 1997. Enhancing bioarchaeological interpretation using indicator groups: Stable manure as a paradigm. Journal of Archaeological Science 24, $663-73$.
Kenward, H. K., Hall, A. R. and Jones, A. K. G. 1984. Turf Roofs and Urban Archaeological Build-up. Unpublished Environmental Archaeology Unit Report 84/15.

Kirby, J. J. H. and Rayner, A. D. M. 1988. Disturbance, decomposition and patchiness in thatch. Proceedings of the Royal Society of Edinburgh 94B, 145-53.

Kirby, J. J. H. and Rayner, A. D. M. 1989. The deterioration of thatch roofs. International Biodeterioration 25, 21-6.

Kloet, G. S. and Hincks, W. D. 1977. A Check List of British Insects. Coleoptera and Strepsiptera (Handbook for the Identification of British Insects 11,3). London: Royal Entomological Society.

Moffett, L. C. and Smith, D. N. 1996. Insects and plants from a Late Medieval tenement in Stone, Staffordshire. Circaea 12, 157-75.

Smith, D. N. 1996a. Thatch, turves and floor deposits: a survey of Coleoptera in materials from abandoned Hebridean blackhouses and the implications for their visibility in the archaeological record. Journal of Archaeological Science 23, 161-74.

Smith, D. N. 1996b. Hebridean blackhouses and a speculative history of the 'culture favoured' Coleoptera of the Hebrides, pp. 207-117 in Gilbertson, D., Kent, M. and Grattan, J. (eds.), The Outer Hebrides: The Last 14,000 Years. Sheffield: Sheffield Academic Press.

Smith D. N. 1998. Beyond the barn beetles: Difficulties in using some Coleoptera as indicators for stored fodder. Environmental Archaeology 1, 63-70.

Smith, D., Letts, J. P. and Cox, A. 1999. Coleoptera from Late Medieval smoke blackened thatch (SBT): its archaeological implications. Environmental Archaeology 4, 9-18.

Woodroffe, G. E. and Southgate, B. J. 1952. Birds' nests as a source of domestic pests. Proceedings of the Zoological Society of London 121, 55-62. 